\title{
Terhesség és akut ischaemiás stroke
}

\author{
Ifj. Bereczki Dániel dr. ${ }^{1,2}$ \\ ${ }^{1}$ Magyar Honvédség Egészségügyi Központ, Neurológiai Osztály, Budapest \\ ${ }^{2}$ Semmelweis Egyetem, Szentágothai János Idegtudományi Doktori Iskola, Budapest
}

\begin{abstract}
A graviditás alatt jelentkező ischaemiás stroke jelentős tényezője mind az anyai, mind a magzati morbiditásnak és mortalitásnak. A terhesség és gyermekágy során észlelt nagyobb kockázatot egyfelől a graviditással összefüggő haemostaseologiai és hemodinamikai változások, másfelől különböző, a terhességre specifikus és nem specifikus kockázati faktorok eredményezik. A diagnosztika, akut terápia és prevenció területén fontos kérdés a beavatkozások esetleges magzatkárosító veszélye. Multicentrikus regiszter létrehozása mindenképpen kívánatos volna a terhességi stroke alaposabb megismeréséhez. Tekintettel arra, hogy nagy esetszámú, randomizált, kontrollált vizsgálatok és ezekre alapozott definitív irányelvek nem állnak rendelkezésre, a terhesség alatt jelentkező akut stroke során minden esetben szakértők bevonásával és a haszon-kockázat megfelelő értékelésével kell egyénre szabott döntést hozni. Orv. Hetil., 2016, 157(20), 763-766.
\end{abstract}

Kulcsszavak: terhesség, stroke, ischaemiás stroke

\section{Pregnancy and acute ischemic stroke}

Pregnancy-related ischemic strokes play an important role in both maternal and fetal morbidity and mortality. Changes in hemostaseology and hemodynamics as well as risk factors related to or independent from pregnancy contribute to the increased stroke-risk during gestation and the puerperium. Potential teratogenic effects make diagnostics, acute therapy and prevention challenging. Because randomized, controlled trials are not available, a multicenter registry of patients with gestational stroke would be desirable. Until definite guidelines emerge, management of acute ischemic stroke during pregnancy remains individual, involving experts and weighing the risks and benefits.

Keywords: stroke, pregnancy, ischemic stroke

Bereczki, D. Jr. [Pregnancy and acute ischemic stroke]. Orv. Hetil., 2016, 157(20), 763-766.

(Beérkezett: 2016. február 12.; elfogadva: 2016. március 10.)

\section{Rövidítések}

CT = komputertomográfia; DWI = diffusion-weighted imaging; $\mathrm{LMWH}=$ low molecular weight heparin; MRI = mágnesesrezonancia-vizsgálat; rtPA = rekombináns humán szöveti plazminogén aktivátor; TOF = time-of-flight; UFH = unfractionated heparin

Ischaemiás stroke-ról beszélünk, ha a neurológiai funkciózavar hátterében fokális agyi, gerincvelői vagy retinalis infarktus áll [1]. A terhesség alatt jelentkező agyi érkatasztrófa ugyan ritka esemény, mégis az egyébként alacsony rizikójú fiatal populációban bekövetkező strokeok 12-35\%-áért és az anyai mortalitás 12\%-áért felelős $[2,3]$. A gesztáció során a legnagyobb kockázatot a szü- lés körüli és gyermekágyi időszak jelenti [4]. Az ischaemiás stroke-ok 100000 szülésre vonatkoztatott gyakorisága 4,3 és 210 közötti [5], azonban a szülési átlagéletkor elmúlt három évtizedben 24,6 évről 27,2 évre történő növekedésével [6] - és ezzel párhuzamosan a társuló cardiovascularis rizikófaktorok gyarapodásával [7] - összhangban emelkedő tendenciát mutat: az Amerikai Egyesült Államokban 1994 és 2007 között az antenatalis és post partum stroke miatti hospitalizációk 47\%-kal, illetve $83 \%$-kal nőttek [8].

\section{Patogenezis és kockázati tényezők}

A terhesség során észlelt emelkedett stroke-kockázathoz több tényező is hozzájárul. Ezek egyfelől a graviditással 
összefüggő haemostaseologiai és hemodinamikai változások, másfelől különböző, a terhességre specifikus és nem specifikus kockázati faktorok.

A hypercoagulabilitashoz vezető tényezők közül kiemelendő a procoagulans faktorok (I, II, VII, VIII, IX és $\mathrm{X})$ szintjének emelkedése, az alvadást gátló fehérjék hatékonyságának csökkenése (alacsonyabb protein S-aktivitás, megnövekedett protein C-rezisztencia), a magasabb fibrinkoncentrációk és a csökkent fibrinolitikus aktivitás [9]. A haemostaseologiai változások - feltehetően a placenta eltávolításakor az anyai keringésbe jutó thromboplasticus anyagok következtében - legkifejezettebbek a szülés körüli és közvetlen post partum időszakban, és körülbelül a szülést követő három héttel térnek vissza a kiindulási értékre [10]. Mindazonáltal a szülés után 12 hétig szignifikánsan emelkedett a thromboticus események (stroke, myocardialis infarctus, vénás thromboembolia) kockázata a nem terhes állapothoz képest [11].

A terhességre specifikus, stroke-rizikót növelő betegségek közé tartozik a várandós nók mintegy 6-8\%-át érintő [12] és a gesztáció során mintegy négyszeres kockázatot jelentő [13] praeeclampsia (és ennek súlyosabb formái: az eclampsia, illetve a haemolysissel, emelkedett májenzimekkel és alacsony thrombocytaszámmal jellemzett HELLP-szindróma [hemolysis, elevated liver enzymes, low platelet count]), valamint olyan ritka kórállapotok, mint post partum cerebralis angiopathia, peri partum cardiomyopathia, choriocarcinoma vagy amnionfolyadék-embolisatio [5]. További, terhességi strokekal asszociált faktorok közé tartoznak többek között a császármetszés, szüléssel kapcsolatos komplikációk (infekció, transzfúzió, post partum vérzés, folyadék- és elektrolitháztartás-zavarok), magasabb anyai életkor, fekete rassz, hypertonia, diabetes, szívbillentyü-betegség, migrén, szisztémás lupus erythematosus, thrombocytopenia, véralvadási zavarok, sarlósejtes anaemia, illetve olyan életmódbeli sajátosságok, mint dohányzás, alkoholfogyasztás vagy droghasználat $[13,14]$.

Bár a praeeclampsia-eclampsia és a cardiogen embolisatio képezik a leggyakoribb stroke-etiológiákat a terhesség során, az esetek egy jelentős részében (28-46\%) a kiváltó tényezốt végül nem sikerül azonosítani (úgynevezett cryptogen stroke) [5]. Tekintettel arra, hogy gyakran fiatal, cardiovascularis rizikófaktoroktól mentes betegekről van szó, szükség lehet ritkább okok, mint például nyaki érdissectio vagy - különösen a hypercoagulabilis állapotra tekintettel - nyitott foramen ovalén keresztüli paradox embolisatio után kutatni.

\section{Diagnosztika, terápia és prevenció}

Az akut stroke általános ellátásának és másodlagos megelőzésének részletes ismertetését illetően utalunk az aktuális irányelvekre $[15,16]$. Terhesség szempontjából külön tárgyalandó a neuroradiológiai képalkotás, az akut terápia és a szekunder prevenció - ezen belül az antithromboticus kezelés - potenciális magzatkárosító veszélye.

\section{Diagnosztika}

Kizárólag a klinikai tünetek alapján nem lehet eldönteni, hogy egy adott betegnél ischaemiás vagy vérzéses stroke áll-e fenn. Amennyiben tehát egy terhes nőnél felmerül agyi érkatasztrófa lehetősége, a pontos diagnózishoz és az adekvát terápia megválasztásához elengedhetetlen agyi képalkotó vizsgálat elvégzése. Már egy natív koponya-CT képes kizárni egy esetleges vérzést vagy más, a szisztémás thrombolysist kontraindikáló állapotot [15]. A koponya-MR-szekvenciák közül a citotoxikus oedemát akár percekkel az ischaemia megjelenése után jelző diffúziósúlyozott képalkotás (diffusion-weighted imaging - DWI) rendelkezik messze a legnagyobb specificitással és szenzitivitással a natív koponya-CT-vel és a többi MR-szekvenciával összehasonlítva [15]. Amennyiben mechanikus thrombectomia lehetősége jön szóba, noninvazív intracranialis vascularis képalkotás (például CTangiográfia) szükséges [17]. A terhes nő képalkotó vizsgálatakor felmerülő magzati kockázat lehetősége CT esetén egyfelől az ionizáló sugárzás, másfelől a jódtartalmú kontrasztanyag esetleges terato- és mutagenitásából ered, amely elsősorban az alkalmazott sugárdózistól és a születendő gyermek fejlődési stádiumától függ [18]. Koponya-CT során a magzat nem esik közvetlenül a röntgennyaláb útjába, így csak a szórt sugárzásból eredő expozíciónak van kitéve. Ennek becsült értéke kevesebb, mint az egész terhesség során észlelt háttérsugárzás egyhuszada [19]. Bár a CT-angiográfiáknál használt jódtartalmú kontrasztanyag átjut a placentán [20], állatkísérletekben és terhes nóknél elvégzett vizsgálatok után nem észleltek teratogén vagy mutagén hatást [20-22]. Ennek ellenére általános irányelvként elmondható, hogy jódtartalmú kontrasztanyag a terhesség során csak kivételes esetekben adható, amennyiben pedig alkalmazása szükségessé válik, úgy - a magzati pajzsmirigyet potenciálisan szupprimáló hatására tekintettel - használatát követően az első post partum héten a magzati pajzsmirigyfunkció ellenőrzése szükséges [23-25]. Mivel a laktációs időszakban intravénásan adott jódtartalmú kontrasztanyagnak lipidoldékonysága miatt csak kevesebb mint 0,01\%-a jut végül az újszülött keringésébe, a vizsgálatot követően nincs szükség a szoptatás szüneteltetésére [26]. Terhesség során képalkotó diagnosztika tekintetében a választandó módszer (az ultrahang mellett) az MR [24], amelynek egyik legfőbb elönye a CT-vel szemben az ionizáló sugárzás hiánya. A felmerülő esetleges magzati teratogén, szöveti hőmérsékletet káros mértékben emelő, illetve halláskárosító hatásokat az eddigi vizsgálatok nem bizonyították [27]. Mindezek alapján egyes ajánlások szerint radiológus szakértő bevonásával és a haszonkockázat megfelelő értékelésével a terhesség bármely szakában (trimesztertől függetlenül) végezhető $\mathrm{MR}$ vizsgálat [21]; más irányelvek a terhesség első trimeszterében fokozott elővigyázatosságra hívják fel a figyelmet és csak klinikailag elengedhetetlen esetekben javasolják MR elvégzését, míg a második és harmadik 
trimeszterben a 3 teslás vagy annál kisebb erőterű $M R-t$ biztonságosnak ítélik [28]. Az MR-képalkotás során az agyi vasculatura megjelenítésére lehetőség van kontrasztanyagot nem igénylő, úgynevezett time-of-flight (TOF) szekvenciával, illetve gadolíniumtartalmú kontrasztanyag adásával. Utóbbi vízoldékony és átjutva a placentán végül megjelenik a magzat vérkeringésében. Állatkísérletek során - ismétlődő magas dózisok esetén - teratogénnek bizonyult [27]. Az aktuális álláspont szerint a gadolíniumtartalmú kontrasztanyag kerülendő és csak olyan klinikai szituációkban javasolt, ahol a diagnózis szempontjából elengedhetetlen az alkalmazása [21]. Tekintettel arra, hogy a szoptatás időszakában intravascularisan adott gadolíniumnak mindössze kevesebb mint 0,0004\%-a jut az újszülött keringésébe, nem szükséges a kontrasztanyagos vizsgálatot követően a szoptatást szüneteltetni [26].

\section{Terápia}

A jelenleg érvényben lévő akut stroke terápiás ajánlások a terhességet „relatív kizárási kritériumként” értékelik, azaz bizonyos körülmények között, a haszon-kockázat gondos mérlegelésével, a szisztémás thrombolysis végrehajtható [15]. Az intravénás vérrögoldástól való félelem a beavatkozáshoz használt rekombináns humán szöveti plazminogén aktivátor (rtPA, altepláz) potenciális magzatkárosító hatásából, illetve az esetleges - elsősorban uterinalis és placentaris - vérzéses szövődményekből ered. Az altepláz nem jut át a placentán és állatkísérletek során $1 \mathrm{mg} / \mathrm{kg}$ dózisban nem mutatott teratogén hatást [29]. A terhesség során alkalmazott szisztémás vérrögoldásról szóló esetismertetések alapján a jelenlegi álláspont szerint a beavatkozás az anya közepes vagy súlyos fokú stroke-ja esetén, szülész-nőgyógyásszal (és neonatológussal) történt egyeztetést követően, a potenciális haszon és a felmerülő rizikó megfelelő értékelése mellett végrehajtható $[15,29]$. Nyolc randomizált klinikai vizsgálat pozitív eredménye alapján az akut stroke ellátására vonatkozó legújabb irányelvek válogatott betegcsoportnál lehetővé teszik mechanikus thrombectomia elvégzését [17]. Várandósság alatti endovascularis intervenció során megfelelő árnyékolással (ólomkötény) az ionizáló sugárzás adverz hatásaiból eredő rizikó minimalizálható [30]. Terhesség során jelentkező akut stroke kapcsán végrehajtott mechanikus thrombectomiáról jelenleg még nincs publikált adat.

\section{Prevenció}

A másodlagos stroke megelőzésének tekintetében szükség lehet a terhesség során valamilyen antithromboticum (antikoaguláns vagy thrombocytaaggregáció-gátló) beállítására. A vonatkozó ajánlások [16] az alábbiak:
1. Amennyiben olyan magas kockázatú állapot áll fenn, ami a terhességen kívül szükségessé tenné antikoaguláns bevezetését, az alábbi lehetőségek jönnek szóba: a) napi kétszeri alacsony molekulasúlyú heparin (low molecular weight heparin - LMWH; anti-Xa-szint alapján illesztve) a terhesség során végig, vagy

b) napi kétszeri nem frakcionált heparin (unfractionated heparin - UFH; APTI vagy anti-Xa-szint alapján illesztve) a terhesség során végig, vagy

c) LMWH vagy UFH (fenti rezsim szerint) a 13. terhességi hétig, majd orális antikoaguláns beállítása a szülés előtti időszakig, amikor LMWH vagy UFH kerül visszaállításra.

2. Azoknál a terhes nóknél, akik LMWH-terápiában részesülnek valamilyen nagy kockázatú állapot miatt, a szülés előtt legalább 24 órával érdemes leállítani az antikoagulációt.

3. Amennyiben az első trimeszter során olyan alacsony kockázatú állapot áll fenn, ami a terhességen kívül thrombocytaaggregáció-gátló szedését indikálná, legfeljebb LMWH vagy UFH jön szóba a klinikai állapot figyelembevételével.

4. Az aszpirin átjut a placentán és összefüggést találtak az első trimeszterbeli használata, illetve a gastroschisis és anophthalmia/microphthalmia között [31]. Az első trimeszter után alacsony dózisú aszpirin (50-150 $\mathrm{mg} / \mathrm{nap})$ szedése elfogadható. Alternatív thrombocytaaggregáció-gátlók és új típusú orális antikoagulánsok terhesség alatti alkalmazhatóságáról egyelőre nem rendelkezünk elegendő humán adattal.

\section{Prognózis}

A graviditás során bekövetkező ischaemiás stroke anyai prognózisát illetően kevés adat áll rendelkezésre. Bár egy korábbi tanulmány szerint az anyai halálozás 26\% [32], újabb vizsgálatok $14 \%$ alatti mortalitást említenek [5]. A magzati halálozási arány körülbelül 12\% [3]. A rekurrens ischaemiás stroke kockázata alacsony, l évre 1\%, 5 évre $2 \%$ [33].

\section{Következtetések}

A terhességi stroke összességében ritka esemény, mégis jelentősen hozzájárul mind az anyai, mind a magzati morbiditáshoz és mortalitáshoz. Multicentrikus regiszter létrehozása mindenképpen kívánatos volna e betegcsoport alaposabb megismeréséhez. Tekintettel arra, hogy nagy esetszámú, randomizált, kontrollált vizsgálatok és ezekre alapozott definitív irányelvek nem állnak rendelkezésre, a terhesség során jelentkező akut stroke menedzsmentje mind a diagnosztika, mind a terápia területén egyaránt kihívást jelentő feladat, ahol minden esetben szakértők bevonásával és a haszon-kockázat megfelelő értékelésével kell egyénre szabott döntést hozni. 
Anyagi támogatás: A közlemény megírása, illetve a kapcsolódó kutatómunka a KTIA-NAP-13-1-2013-0001 pályázati támogatásban részesült.

A cikk végleges változatát a szerző elolvasta és jóváhagyta.

Érdekeltségek: A szerzőnek nincsenek érdekeltségei.

\section{Irodalom}

[1] Sacco, R. L., Kasner, S. E., Broderick, J. P., et al.: An updated definition of stroke for the 21 st century. A statement for healthcare professionals from the American Heart Association/American Stroke Association. Stroke, 2013, 44(7), 2064-2089.

[2] Feske, S. K.: Stroke in pregnancy. Semin. Neurol., 2007, 27(5), $442-452$

[3] Treadwell, S. D., Thanvi, B., Robinson, T. G.: Stroke in pregnancy and the puerperium. Postgrad. Med. J., 2008, 84(991), 238245 .

[4] Sharshar, T., Lamy, C., Mas, J. L.: Incidence and causes of strokes associated with pregnancy and puerperium. A study in public hospitals of Ile de France. Stroke, 1995, 26(6), 930-936.

[5] Del Zotto, E., Giossi, A., Volonghi, I., et al.: Ischemic stroke during pregnancy and puerperium. Stroke Res. Treat., 2011, 2011, 606780

[6] Mathews, T. J., Hamilton, B. E.: Mean age of mother, 19702000. Natl. Vital Stat. Rep., 2002, 51(1), 1-13.

[7] Luke, B., Brown, M. B.: Elevated risks of pregnancy complications and adverse outcomes with increasing maternal age. Hum. Reprod., 2007, 22(5), 1264-1272.

[8] Kuklina, E. V., Tong, X., Bansil, P., et al.: Trends in pregnancy hospitalizations that included a stroke in the United States from 1994 to 2007. Reasons for concern? Stroke, 2011, 42(9), 25642570.

[9] Hellgren, M., Blombäck, M.: Studies on blood coagulation and fibrinolysis in pregnancy, during delivery and in puerperium. I. Normal condition. Gynecol. Obstet. Invest., 1981, 12(3), 141154 .

[10] Bremme, K. A.: Haemostatic changes in pregnancy. Best Pract. Res. Clin. Haematol., 2003, 16(2), 153-168.

[11] Kamel, H., Navi, B. B., Sriram, N., et al.: Risk of a thrombotic event after the 6-week postpartum period. N. Engl. J. Med., 2014, 370(14), 1307-1315.

[12] ACOG Practice Bulletin No. 33: Diagnosis and management of preeclampsia and eclampsia. Obstet. Gynecol., 2002, 99(1), 159-167.

[13] James, A. H., Bushnell, C. D., Jamison, M. G., et al.: Incidence and risk factors for stroke in pregnancy and puerperium. Obstet. Gynecol., 2005, 106(3), 509-516.

[14] Lanska, D. J., Kryscio, R. J.: Risk factors for peripartum and postpartum stroke and intracranial venous thrombosis. Stroke, 2000, 31(6), 1274-1282.

[15] Jauch, E. C., Saver, J. L., Adams, H. P. Jr., et al.: Guidelines for the early management of patients with acute ischemic stroke: a guideline for healthcare professionals from the American Heart Association/American Stroke Association. Stroke, 2013, 44(3), 870-947.

[16] Kernan, W. N., Ovbiagele, B., Black, H. R., et al.: Guidelines for the prevention of stroke in patients with stroke and transient ischemic attack: a guideline for healthcare professionals from the American Heart Association/American Stroke Association. Stroke, 2014, 45(7), 2160-2236.
[17] Powers, W. J., Derdeyn, C. P., Biller, J., et al.: 2015 American Heart Association/American Stroke Association focused update of the 2013 guidelines for the early management of patients with acute ischemic stroke regarding endovascular treatment: a guideline for healthcare professionals from the American Heart Association/American Stroke Association. Stroke, 2015, 46(10), 3020-3035.

[18] American College of Radiology: ACR-SPR practice parameter for imaging pregnant or potentially pregnant adolescents and women with ionizing radiation. Resolution 39. ACR, Reston (VA), 2014.

[19] Mortimer, A. M., Bradley, M. D., Likeman, M., et al.: Cranial neuroimaging in pregnancy and the post-partum period. Clin. Radiol., 2013, 68(5), 500-508.

[20] Webb, J. A., Thomsen, H. S., Morcos, S. K., et al.: The use of iodinated and gadolinium contrast media during pregnancy and lactation. Eur. Radiol., 2005, 15(6), 1234-1240.

[21] Kanal, E., Barkovich, A. J., Bell, C., et al.: ACR Guidance document on MR safe practices: 2013. J. Magn. Reson. Imaging, 2013, 37(3), 501-530.

[22] Atwell, T. D., Lteif, A. N., Brown, D. L., et al.: Neonatal thyroid function after administration of IV iodinated contrast agent to 21 pregnant patients. Am. J. Roentgenol., 2008, 191(1), 268271.

[23] The Royal College of Radiologists: Standards for intravascular contrast agent administration to adult patients. The Royal College of Radiologists, London, 2015.

[24] American College of Obstetricians and Gynecologists: Guidelines for diagnostic imaging during pregnancy and lactation. Committee Opinion No. 656. Obstet. Gynecol., 2016, 127(2), e75-e80.

[25] Patel, S. J., Reede, D. L., Katz, D. S., et al.: Imaging the pregnant patient for nonobstetric conditions: algorithms and radiation dose considerations. RadioGraphics, 2007, 27(6), 1705-1722.

[26] American College of Radiology: Administration of contrast media to pregnant or potentially pregnant patients. In: ACR Manual on Contrast Media. Version 10.1. ACR, Reston (VA), 2015, 95-98.

[27] Chen, M. M., Coakley, F. V., Kaimal, A., et al.: Guidelines for computed tomography and magnetic resonance imaging use during pregnancy and lactation. Obstet. Gynecol., 2008, 112(2 Pt 1), 333-340.

[28] Patenaude, $\Upsilon$., Pugash, D., Lim, K., et al.: The use of magnetic resonance imaging in the obstetric patient. J. Obstet. Gynaecol. Can., 2014, 36(4), 349-363.

[29] Demaerschalk, B. M., Kleindorfer, D. O., Adeoye, O. M., et al.: Scientific rationale for the inclusion and exclusion criteria for intravenous alteplase in acute ischemic stroke. A Statement for Healthcare Professionals From the American Heart Association/ American Stroke Association. Stroke, 2016, 47(2), 581-641.

[30] Ishii, A., Miyamoto, S.: Endovascular treatment in pregnancy. Neurol. Med. Chir. (Tokyo), 2013, 53(8), 541-548.

[31] Hernandez, R. K., Werler, M. M., Romitti, P., et al.: Nonsteroidal antiinflammatory drug use among women and the risk of birth defects. National Birth Defects Prevention Study. Am. J. Obstet. Gynecol., 2012, 206(3), 228.el-228.e8.

[32] Cross, J. N., Castro, P. O., Jennett, W. B.: Cerebral strokes associated with pregnancy and the puerperium. Br. Med. J., 1968, 3(5612), 214-218.

[33] Frontera, J. A., Ahmed, W.: Neurocritical care complications of pregnancy and puerperium. J. Crit. Care, 2014, 29(6), 10691081 .

(Ifj. Bereczki Dániel dr., Budapest, Róbert Károly krt. 44., 1134 e-mail: bereczki.daniel@hotmail.com) 